\title{
How Are Different Slack Resources Translated into Firm Growth? Evidence from China
}

\author{
Weiqi Dai ${ }^{1} \&$ Wiboon Kittilaksanawong ${ }^{2}$ \\ ${ }^{1}$ School of Business Administration, Zhejiang University of Finance \& Economics, People’s Republic of China \\ ${ }^{2}$ Faculty of Management, Nagoya University of Commerce and Business, Japan \\ Correspondence: Wiboon Kittilaksanawong, Faculty of Management, Nagoya University of Commerce and \\ Business, Nisshin, Aichi, 470-0193, Japan. Tel: 81-561-73-2111. E-mail: wiboon@nucba.ac.jp
}

Received: December 3, 2013

Accepted: December 20, 2013

Online Published: January 23, 2014

doi: $10.5539 /$ ibr.v7n2p1

URL: http://dx.doi.org/10.5539/ibr.v7n2p1

\begin{abstract}
This paper aims to clarify types of slack resources and mechanisms through which these resources are translated into the growth of transition economy firms. It compares human resource slack and financial slack in terms of their 'proactivity' to unveil their differing effects on firm growth. This paper further highlights firm-level entrepreneurial activities as a mechanism through which these resources are translated into firm growth. Data was collected from senior managers through a questionnaire survey from manufacturing firms in China's Zhejiang province. This paper demonstrates that not all slack resources are readily turned into firm growth as argued in most of prior studies. In particular, only proactive HR slack is directly related to firm growth, while financial slack fuels firm growth via HR slack. Besides, HR slack also propels firm growth partially through various corporate entrepreneurial activities. This paper proposes and demonstrates that 'proactivitity' is a crucial dimension that explains the differing effects of slack resources on firm growth. In addition, corporate entrepreneurial activities are an underlying mechanism through which HR slack is translated into firm growth.
\end{abstract}

Keywords: slack resource, corporate entrepreneurship, firm growth, proactivity

\section{Introduction}

Growth in terms of firm size is a desirable objective for both owners and managers in most firms (Brush, Bromiley, \& Hendrickx, 2000). Scholars have long argued that both tangible and intangible resources play a pivotal role in stimulating firm growth (e.g., Penrose, 1959). However, extant studies that investigate the relationships between resource availability and firm growth have shown mixed results. Some studies have found that the resources controlled by a firm enhance growth (e.g., Bamford, Dean, \& McDougall, 1997; Cooper, Gimeno-Gascon, \& Woo, 1994), whereas others have reported that resource differences among firms are not related to their growth differences (e.g., Shrader \& Simon, 1997). Some scholars have argued that the combination of resources with particular business strategies influences expansion (e.g., Bamford et al., 1997), however, others have observed either inconsistent results associated with such interactions (e.g., Chandler \& Hanks, 1994) or even no growth implications being derived from such contingencies (e.g., Brush \& Chaganti, 1999).

These mixed findings may be resulted from different conceptions of resources related to the expansion. In essence, it is the slack resources that drive a firm's growth rather than 'the total amount of resources' held by a firm (e.g., Penrose, 1959). The slack resources represent the difference between the resources currently possessed by a firm and the minimum resources requirement of the current business (Cohen, March, \& Olsen, 1972). Slack resources provide firms with additional 'productive service' to take advantage of opportunities within the environment and fuel the firms to expand. Therefore, it is meaningful to investigate the relationships between slack resources and firm growth instead of 'total amount of resources' and firm growth (Penrose, 1959; Thompson, 1967).

In the literature, there are two distinctive views on the relationship between slack resources and firm growth. Some scholars suggest that in firms with abundant slack resources, decision makers are able to readily mobilize these resources and pursue opportunities to expansion (Penrose, 1959; Thompson, 1967). However, other scholars assert that slack is not always beneficial for a firm in that it may encourage suboptimal firm behavior 
(Simon, 1957; March \& Simon, 1958). High level of slack resources leads to risk aversion, which results in low exploration, passivity in organizational responses, and increased motivation to capitalize on known competencies through exploitation (Levinthal \& March, 1993; Voss, Sirdeshmukh, \& Voss, 2008). With a pool of slack resources, firms may be kept 'safe' because such resources shield them from shocks in their external environment. Therefore, decision makers in these firms may be too optimistic about their future and lose their motivations for expansion. In sum, the relationships between slack resources and firm growth remain controversial and inconclusive.

We posit that slack resources differ along various dimensions. Therefore, we should not take 'slack resources' as a whole in examining their effects on firm behavior and performance. Rather, we have to divide slack resources into different types in a meaningful way and explore their likely heterogeneous impacts on firm growth. To fulfill such intention, this paper focuses on two types of slack resources that have been frequently addressed in prior studies (e.g., Voss et al., 2008; Mishina, Pollock, \& Porac, 2004), namely human resource slack and financial slack, and investigate their specific effects on firm growth. Apart from such dimensions as rarity, stickiness, and absorption, we posit that slack resources are critically different in terms of their 'proactivity' (e.g., the extent to which a particular type of resources is able to spontaneously devote itself to specific uses) and that slack resources with a higher level of proactivity are more able to positively fuel firm growth.

In addition, prior studies have largely examined the main effects of slack resources on firm growth without explaining clearly the mechanisms through which these resources act on firm growth (e.g., Su, Xie, \& Li, 2009). To address this issue, we argue that corporate entrepreneurship (e.g., entrepreneurial activities by incumbent firms such as entry into new industries or new markets) mediates the link between slack resources and firm growth. Essentially, it is through corporate entrepreneurial activities that a firm's internal slack resources are mobilized and deployed to appropriate use and thereby leading to firm growth.

To test our propositions, we conduct a questionnaire survey with manufacturing firms in China's Zhejiang province, one of the most entrepreneurial areas in the country. China is a transition economy with an impressive rate of economic growth. Many Chinese firms have transformed from a state-owned enterprise to a more privately-owned and market-oriented enterprise. Meanwhile, entrepreneurship is increasingly supported by the governments and embraced by the Chinese society. During this transition period, firms in China hold significantly different and unbalanced levels of financial and human slack resources, entrepreneurial activities, and growth rates. Therefore, employing firms in China as the research context provides us a great opportunity to extend the extant literature pertinent to slack resources, corporate entrepreneurship, and firm expansion.

This paper compares the effects of two distinct slack resources (e.g., human resource slack and financial slack) on entrepreneurial activities and firm growth and examines the mediating role of corporate entrepreneurship. The paper not only extends the discussions on the slack resources - firm growth link, but also reveals the mechanism through which slack resources spur firm expansion. In particular, we put forth 'proactivity' as a critical dimension of slack resources that has not been discussed intensively in prior research. In addition, we extend the geographical reach of previous studies on slack resource that are mainly conducted with firms in the western developed countries to transition China economy. Therefore, investigating the slack resource within firms in China may provide fresh ideas and shed new lights on some unanswered questions.

The remainder of the paper is structured as follows. We first build a conceptual model on the relationships among slack resources, corporate entrepreneurship and firm growth. We then introduce the research methodology and report the empirical findings. Finally, we discuss the implications of the findings and draw conclusions.

\section{Theory and Hypotheses}

\subsection{The Distinctions between Human Resource and Financial Slack}

Slack refers to a level of resources in an organization that exceeds the minimum need of ongoing business operations (Bourgeois, 1981). As a critical concept in strategic management and organization theory, slack is used to explain a variety of phenomena such as organizational goals conflict, organizational power, efficiency, as well as innovation and performance (Nohria \& Gulati, 1996). Prior research primarily divides slack resources into two categories according to the extent of which they are absorbed in ongoing operations (Sharfman et al., 1988), namely absorbed and unabsorbed slack. The former refers to redundant resources within the current operations. Examples include excessive production capacity (Greve, 2003). The latter are resources which are currently not committed to any business activities and thus can be redeployed readily within organizations (Sharfman et al., 1988; Tan \& Peng, 2003). Examples include cash or other assets that are readily available for use for a variety of purposes. 
Slack is in different types of resources that encompasses various excessive inputs such as redundant employees, unused physical facilities, and unutilized cash flows. Among them, financial and human resources are two broad slack resource categories that have received more attention in prior research (e.g., Mishina et al., 2004; Voss et al., 2008). Human resource slack, whether absorbed or not, includes excessive employees with relatively high expertise (e.g., R\&D personnel) or relatively low expertise (e.g., workers engaging in labor-intensive job). In this paper, we limit our attention to redundant managerial talents and $R \& D$ personnel within firms. Particularly, we focus on redundant employees with relatively high professional expertise. Financial slack refers to the level of liquid assets, such as cash on hand that is readily available for use in an organization (Kraatz \& Zajac, 2001).

Prior studies have unveiled the distinctions between these two types of slack resources. For instance, Mishina et al. (2004) posit that human resource slack is 'stickier' than financial slack and the stickiness influences the flexibility with which two types of slack resources can be deployed. Voss et al. (2008) assert that human resource slack and financial slack differ along two dimensions, namely rarity and absorption. On one hand, human resource slack is rarer than financial slack due to limited availability in the factor market and time-consuming and effortful accumulation process within an organization. On the other hand, human resource slack could be both absorbed and unabsorbed while financial slack is usually unabsorbed.

Obviously, prior studies have provided insights into the distinctions between human resource slack and financial slack. Nevertheless, we argue that they overlook proactivity as a crucial dimension in their distinctions which could be used to explain the differing effects of slack resources on firm growth. One thing for sure is that human being is the most proactive or active element in the production activities within an organization because other types of physical resources are all deployed and utilized by human beings. We define proactivity as the extent to which a kind of resources is able to devote itself to specific uses spontaneously. This characteristic can indeed be attributed to human, rather than to other physical or material resources (e.g., financial resources). Essentially, only human resource is able to mobilize and deploy itself and other kinds of resources within a firm. Therefore, slack in human resource (human resource slack) is more proactive than that in financial resource (financial slack). As we will demonstrate, the dimension of proactivity is of importance in explaining the differing effects of human resource slack and financial slack on firm growth and corporate entrepreneurship.

\subsection{Two Sorts of Slack Resources and Firm Growth}

In the Penrosian theory of firm growth, the amount of 'productive services' provided by firm resources, determines the rate of firm growth (Penrose, 1959). In essence, unabsorbed slack resources are unused resources whose 'productive services' are not being exploited. Expansion provides a way of using services of these unused resources and capturing their value. Firms with slack resources thus have the capability to grow and accordingly, slack resources have inherent associations with firm growth (Penrose, 1959). Nevertheless, slack resources differ in many ways which may, in turn, constrain their effects on firm growth.

Financial slack, such as cash on hand, refers to liquid assets that are not committed or absorbed in any current organizational activities (Kraatz \& Zajac, 2001). In order to appropriate its value, a firm's decision makers are motivated to pursue growth opportunities. In this sense, the existence of financial slack resources lays a foundation for firm growth. However, being a sort of 'passive' slack resource, financial resource is unable to deploy itself directly to increase the number of production lines or market segments that subsequently contribute to the firm expansion. Consequently, financial slack, per se, fails to spur firm growth directly. The effects of financial slack on firm growth, to a large extent, hinges on the availability of proactive human resource slack. In this paper, we refer to human resource slack as specialized and skilled human resources that are not committed or absorbed in any current organizational activities. With the existence of human resource slack, the usage of other sorts of slack resources, including financial slack, can be realized. As a matter of fact, it is human being that deploys other sorts of physical slack resources and determines the productive services available for firm growth. Therefore, the availability of human resource slack has a direct bearing on firm growth whereas the financial slack influences firm growth through human resource slack. Hence, we hypothesize:

H1a: Human resource slack has a direct and positive effect on firm growth.

H1b: Financial slack has a positive effect on firm growth but this effect is channeled through human resource slack.

\subsection{Two Sorts of Slack Resources and Corporate Entrepreneurship}

Corporate entrepreneurship refers to firm-level entrepreneurial activities such as entry into new business or markets (Yiu \& Lau, 2008). As a specific type of entrepreneurship, corporate entrepreneurship is also the identification and exploitation of opportunities in the environment (Shane, 1999). With uncommitted but skilled 
personnel, firms are able to monitor or scan the environment persistently and identify available opportunities as well as launch a range of entrepreneurial projects by assembling other types of slack resources. In other words, due to its proactivity, the existence of human resource slack facilitates the implementation of corporate entrepreneurship.

Though financial slack is generic, uncommitted, and unabsorbed, it lacks of proactivity. Firms are not able to deploy financial slack unless they hold adequate proactive human resource slack to utilize it effectively in various strategic or entrepreneurial activities. In particular, deploying financial resources within organizations for strategic or entrepreneurial actions typically involves potential political hurdles among different units holding this type of resources. Therefore, it is imperative that firms hold redundant specialized or skilled personnel to remove the obstacles and redistribute financial slack into appropriate use. Particularly, financial slack, per se, is important for corporate entrepreneurship but due to its lack of proactivity, its impact is dependent on the availability of human resource slack. Hence, we hypothesize:

H2a: Human resource slack has a direct and positive effect on corporate entrepreneurship.

$\mathrm{H} 2 \mathrm{~b}$ : Financial slack has a positive effect on corporate entrepreneurship but this effect is channeled through human resource slack.

\subsection{Corporate Entrepreneurship and Firm Growth}

Following Teece, Pisano, and Shuen (1997), dynamic capability allows firms to integrate, build, and reconfigure internal and external competences to address rapidly changing environments. Dynamic capability is particularly important in the rapidly changing environment and increasing market competition in many transition economies because it enables firms to successfully respond to new emergent opportunities in this environment (Yiu \& Lau, 2008). Corporate entrepreneurship refers to the establishment of a separate corporate organization that is usually in the form of a profit center, strategic business unit, division, or subsidiary to introduce a new product, serve or create a new market, or utilize a new technology (Spann, Adams, \& Wortman, 1988). In the process of corporate entrepreneurship, a firm reconfigures and reassembles internal and external available resources and takes advantages of opportunities in their environment that are subsequently transformed into a firm's profitability and growth. Corporate entrepreneurship involves extending the firm's domain of competence and corresponding opportunity set through internally generated new resource combination (Covin \& Slevin, 1991). Therefore, corporate entrepreneurship embodies a type of firm's dynamic capability (Zahra, Sapienza, \& Davidsson, 2006). By recombining slack resources with other internal and external resources within the process of corporate entrepreneurship, firms are able to develop new products or enter new markets, which in turn, fuel their expansion. Extant empirical research has also suggested the positive relationship between corporate entrepreneurship and growth performance (e.g., Luo, Zhou, \& Liu, 2005; Zahra \& Covin, 1995). Hence, we hypothesize:

H3: Corporate entrepreneurship has a direct and positive effect on firm growth.

\section{Methodology}

\subsection{Sample and Data Collection}

This study employed sample firms from four prominent industrial clusters in China's Zhejiang province for a field survey. These industrial clusters include Shaoxing Textile, Yongkang Hardware, Haining Warp Knitting, and Yuyao Mould. These clusters are all belonging to traditional industrial clusters with high levels of internal interconnectedness.

The reason for adopting survey research is twofold. First, the complete archival data of the sample firms are not available for the research purpose because these firms are mainly private firms. Second, constructs in this study are not all able to be gauged by the available archival data. For instance, the construct of corporate entrepreneurship is usually measured by perceptual multi-item scales in prior studies (e.g., Yiu \& Lau, 2008). Therefore, using questionnaire survey to gather such data is appropriate for this research.

The survey was administrated during October, 2009 and April, 2010. To improve the response rate and data reliability, we distributed the questionnaires with the assistance from the local governments. We received 182 questionnaires back from the total of 700 questionnaires, resulting in a $26 \%$ response rate. The valid number of questionnaires, after excluding incomplete ones, was 157 , accounting for $22.4 \%$ valid response rate. Average firm age, number of employees, and value of assets were 14.4 years, 486 people, and 450.73 million RMB respectively. Private enterprises, state-owned enterprises, and multinational companies accounted for $49.7 \%$, $15.3 \%$, and $32.9 \%$ respectively. The high proportion of private enterprises represents the highly developed market economy of China's Zhejiang province. Table 1 shows the basic information of the sample firms. 
Table 1. Basic information of the sample firms

\begin{tabular}{cccc}
\hline & Category & Frequency & Percentage (\%) \\
\hline Ownership & State-owned & 24 & 15.3 \\
& Private-owned & 78 & 49.7 \\
& Foreign-owned & 18 & 11.5 \\
& Individual or partnership & 34 & 1.9 \\
No response & 3 & 100 \\
\hline Industry & Total & 157 & 36.3 \\
& Textile & 57 & 33.8 \\
& Hardware & 53 & 17.2 \\
& Mould-Making & 27 & 12.7 \\
\hline
\end{tabular}

We asked respondents of the firm at executive levels (e.g., general manager or vice president) or middle-level managers who were fully aware of the overall business of the firm to complete the questionnaire. Among these respondents, $58.6 \%$ were male, $82.25 \%$ were between $30-49$ years old, and $59.9 \%$ had at least college or university education level. All respondents had at least 2 years of work experience with the company, whereas majority of them, $61.8 \%$, had worked with the company for 6-10 years. We ensured the anonymity of the respondents to minimize the bias answers. All statements in the questionnaire were designed such that they were as simple and clear as possible.

\subsection{Measures and Statistical Methods}

Firm growth (Firm_Growth) is the major dependent variable, which is measured from three aspects including, sales growth, market share growth, and growth in number of employees. The respondents were requested to assess the growth of their company relative to the average industry growth, using a seven-point Likert scale, where scale 1 and 7 represented a very low and a very high level of relative growth respectively.

We adopted Yiu and Lau's (2008) scale to gauge the important mediating variable, corporate entrepreneurship (CE). Using 17 items in a 7-point Likert scale, we asked the respondents to indicate the extent to which their company complied with the statement in each item from the lowest score of 0 for 'completely non-compliant' to the highest score of 7 for 'completely compliant'.

Human resource slack (HR_Slack) and financial slack (FI_Slack) are two major independent variables. This study follows Nohria and Gulati (1996) in the measurement of these two variables. Financial slack is measured by three items including, the firm's debt-to-asset ratio, the firm's cash flow available for use by the managers, and the firm's retained profits for use in various business activities. Human resource slack is measured by two items including, the firm's reserve of professional and technical personnel, and the firm's reserve of management talents. We asked the management of the sample firms to base their answers according to the actual situation over the past three years and score them by a 5-point Likert scale.

This study employed exploratory factor analysis, confirmatory factor analysis, and structural equation modeling to test the hypotheses in the proposed conceptual model. We followed Anderson and Gerbing's (1988) two-step structural equation modeling approach. The structural equation modeling consisted of measurement model to measure the relationship between latent variables and their indicators, and structural model to measure the structural relationship between endogenous and exogenous latent variables. We assessed the measurement model to ensure the reliability of our scales prior to the simultaneous estimation of the measurement and structural models.

\section{Empirical Findings}

\subsection{Reliability and Validity of the Constructs}

Table 2 demonstrates the results of exploratory factor analysis for the mediating variable, corporate entrepreneurship. We measure this construct with 17 items in a 7-point Likert scale. The result indicates four 
factors accounting for $72.995 \%$ of the total variance. These four factors are then named as management innovation (MI), product innovation (PI), foreign corporate venturing (FCV), and domestic corporate venturing (DCV). The internal consistency of each factor is tested by $\left(\sum \lambda_{\mathrm{yi}}\right)^{2} /\left(\left(\lambda_{\mathrm{yi}}\right)^{2}+\sum \operatorname{var}\left(\varepsilon_{\mathrm{i}}\right)\right)$ (Fornell \& Larcker, 1981) and 0.7 is used as the reference value (Nunnally, 1978). The value for internal consistency of the four factors as shown on Table 2 is between 0.776 and 0.902 , thereby indicating that all four factors are internally consistent.

Table 2. Exploratory factor analysis

\begin{tabular}{|c|c|c|c|c|}
\hline & $\begin{array}{l}\text { Management } \\
\text { Innovation } \\
\text { (MI) }\end{array}$ & $\begin{array}{l}\text { Product } \\
\text { Innovation } \\
\text { (PI) }\end{array}$ & $\begin{array}{c}\text { Foreign } \\
\text { Corporate } \\
\text { Venturing } \\
(\mathrm{FCV})\end{array}$ & $\begin{array}{c}\text { Domestic } \\
\text { Corporate } \\
\text { Venturing } \\
(\mathrm{DCV})\end{array}$ \\
\hline $\begin{array}{l}\text { CE15: Implement significant adjustments to existing management } \\
\text { system }\end{array}$ & 0.858 & & & \\
\hline $\begin{array}{l}\text { CE16: Implement significant adjustments to existing organizational } \\
\text { structure }\end{array}$ & 0.793 & & & \\
\hline $\begin{array}{l}\text { CE13: Implement significant adjustments to internal operation } \\
\text { process }\end{array}$ & 0.761 & & & \\
\hline $\begin{array}{l}\text { CE17: Implement significant adjustments to human resource } \\
\text { management system }\end{array}$ & 0.757 & & & \\
\hline CE14: Introduce many new management ideas and methods & 0.753 & & & \\
\hline $\begin{array}{l}\text { CE7: Implement significant innovation in existing products or } \\
\text { services }\end{array}$ & & 0.82 & & \\
\hline CE6: Invest significantly in R\&D for new products or services & & 0.813 & & \\
\hline $\begin{array}{l}\text { CE8: Introduce many new concepts and ideas in existing products } \\
\text { or services }\end{array}$ & & 0.796 & & \\
\hline CE5: Launch many new products or services & & 0.765 & & \\
\hline CE12: Significantly expand business in foreign countries & & & 0.831 & \\
\hline CE10: Enter in many new foreign markets & & & 0.806 & \\
\hline CE11: Set up many new foreign subsidiaries & & & 0.796 & \\
\hline CE9: Actively support activities related to foreign expansion & & & 0.78 & \\
\hline CE2: Set up many new domestic subsidiaries & & & & 0.864 \\
\hline CE4: Expand in many domestic and foreign market regions & & & & 0.771 \\
\hline CE1: Enter in many domestic markets & & & & 0.739 \\
\hline CE3: Invest in other domestic companies & & & & 0.549 \\
\hline Cronbach's $\alpha$ coefficient & 0.902 & 0.892 & 0.885 & 0.776 \\
\hline Eigenvalue & 3.662 & 3.22 & 3.023 & 2.505 \\
\hline Explained variance (\%) & 21.539 & 18.942 & 17.781 & 14.733 \\
\hline Cumulative explained variance (\%) & 21.539 & 40.481 & 58.262 & 72.995 \\
\hline
\end{tabular}

Confirmatory factor analysis for corporate entrepreneurship shows that the model for measuring corporate entrepreneurship has a good fit with measurement validity $\left(\chi^{2}(113)=260.969, p<.001 ; \chi^{2} / \mathrm{df}=2.309\right.$; CFI $=.907$; RMSEA $=.092$; IFI $=.910)$. All items correspond to the hypothesized factors. Factor loading for all items except CE3 is greater than the recommended threshold level of .60. Further, all have the aggregate validity highly significant at $\mathrm{p}<.01$. Finally, the single factor model $\left(\chi^{2}(113)=413.873, \mathrm{p}<.001 ; \chi^{2} / \mathrm{df}=3.478\right.$; CFI $=.815 ;$ RMSEA $=.126 ;$ IFI $=.819)$ with four-factor model chi-square also has significant difference $\left(\Delta \chi^{2}(6)=\right.$ 
152.904, $\mathrm{p}<.001$ ), thereby indicating that all four factors differentiate from each other with significantly high validity.

The factor analysis for financial slack and human resource slack is based on five question items. These five key questions can be reduced to form two factors that are able to explain $75.977 \%$ of the total variance. The Cronbach's $\alpha$ coefficient for each factor is .770 and .830 respectively, indicating a good internal consistency and reliability. The results of confirmatory factor analysis also shows that this measure has a good fit measurement validity $\left(\chi^{2}(4)=5.867, \mathrm{p}<.05 ; \chi^{2} / \mathrm{df}=1.467 ; \mathrm{CFI}=.992 ; \mathrm{RMSEA}=.055 ;\right.$ IFI $\left.=.993\right)$. Regarding the factor analysis for firm growth, the three question items are further reduced to one factor, explaining $79.301 \%$, of the total variance and with the Cronbach's $\alpha$ coefficient of .867, indicating a good internal consistency and reliability. Table 3 shows the convergent validity and discrimination validity. Following Fornell and Larcker (1981), both validity tests show that the measurement model in this study has a high statistical significance.

Table 3. Results of measurement model

\begin{tabular}{|c|c|c|c|c|c|c|c|c|c|}
\hline \multirow{2}{*}{ Latent Variable } & \multirow{2}{*}{ Indicator } & \multirow{2}{*}{ AVE } & \multicolumn{7}{|c|}{ Correlation Matrix of Latent Variables } \\
\hline & & & FI_Slack & HR_Slack & MI & PI & FCV & $\mathrm{DCV}$ & Firm_Growth \\
\hline FI_Slack & 3 & .5548 & $(.745)$ & & & & & & \\
\hline HR_Slack & 2 & .7081 & $.384 * *$ & $(.841)$ & & & & & \\
\hline MI & 5 & .6469 & $.242 * *$ & $.385 * *$ & $(.804)$ & & & & \\
\hline PI & 4 & .6829 & $.267 * *$ & $.443 * *$ & $.599 * *$ & $(.826)$ & & & \\
\hline FV & 4 & .6608 & $.295 * *$ & $.472 * *$ & $.451 * *$ & $.436^{* *}$ & $(.813)$ & & \\
\hline DV & 4 & .4883 & .120 & $.315 * *$ & $.397 * *$ & $.412 * *$ & $.366 * *$ & $(.699)$ & \\
\hline Frim_Growth & 3 & .6958 & $.360 * *$ & $.487 * *$ & $.463 * *$ & $.464 * *$ & $.386^{* *}$ & $.314 * *$ & $(.834)$ \\
\hline
\end{tabular}

$* * \mathrm{p}<.01$

\subsection{Assessment of Common Method Bias}

Because the data in this study were collected from self-report questionnaire, common method bias may exist (Krishnan, Martin, \& Noorderhaven, 2006). Following Podsakoff et al. (2003), we conducted a Harman one-factor test and found that this model demonstrated very poor fit, as indicated by the fit indices $\left(\chi^{2}(54)=\right.$ $\left.290.416, \mathrm{p}<.001 ; \chi^{2} / \mathrm{df}=5.378 ; \mathrm{CFI}=.682 ; \mathrm{RMSEA}=.168 ; \mathrm{IFI}=.692\right)$. This result indicates that common method bias is not likely to be a major threat to the subsequent hypothesis testing.

\subsection{Hypothesis Testing Using Structural Model}

We employed structural model to test the relationship between latent variables. The test results of the path coefficients are shown on Table 4 and Figure 1. Statistical test results as shown on Figure 1 with solid lines (dotted lines) indicate significant (non-significant) relationship between latent variables. Human resource slack has a positive effect on firm growth with a statistical significance $(\gamma=.289, \mathrm{p}<.10)$. Therefore, hypothesis 1 a is supported. Financial slack also has a positive effect on firm growth but this effect is channeled through human resource slack. Therefore, hypothesis $1 \mathrm{~b}$ is supported. Further, human resource slack has a significant and positive effect on corporate entrepreneurship $(\gamma=.563, \mathrm{p}<.01)$. Therefore, hypothesis $2 \mathrm{a}$ is supported. Financial slack also has a positive effect on corporate entrepreneurship, but this effect is channeled through human resource slack. Therefore, hypothesis $2 \mathrm{~b}$ is supported. Lastly, corporate entrepreneurship has a positive effect on firm growth with a statistical significance $(\beta=.424, \mathrm{p}<.01)$, therefore hypothesis 3 is supported. The statistical supports for hypothesis 1a, 2a, and 3 also indicate that corporate entrepreneurship essentially acts as a mediator between human resource slack and firm growth. The results of the model fitting indicate a good fit and validity for the relationship among both organizational resource slacks, corporate entrepreneurship, and firm growth $\left(\chi^{2}\right.$ $\left.(48)=81.304, \mathrm{p}<.001 ; \chi^{2} / \mathrm{df}=1.694 ; \mathrm{RMSEA}=.067 ; \mathrm{CFI}=.955 ; \mathrm{IFI}=.957 ; \mathrm{NFI}=.901\right)$. 
Table 4. Estimates of standardized regression weights

\begin{tabular}{ccccccc}
\hline \multicolumn{2}{c}{ Relationship between Variables } & Standardized Regression Weights & S.E. & C.R. & P \\
\hline HR_Slack & $<---$ & FI_Slack & .457 & .148 & 4.051 & $* * *$ \\
CE & $<--$ & FI_Slack & .162 & .164 & 1.525 & .127 \\
CE & $<---$ & HR_Slack & .563 & .135 & 4.942 & $* * *$ \\
Firm_Growth & $<---$ & HR_Slack & .289 & .136 & 2.513 & .012 \\
Firm_Growth & $<--$ & FI_Slack & .128 & .142 & 1.385 & .166 \\
Firm_Growth & $<--$ & CE & .424 & .124 & 3.426 & $* * *$ \\
\hline
\end{tabular}

$* * * \mathrm{p}<.001$.

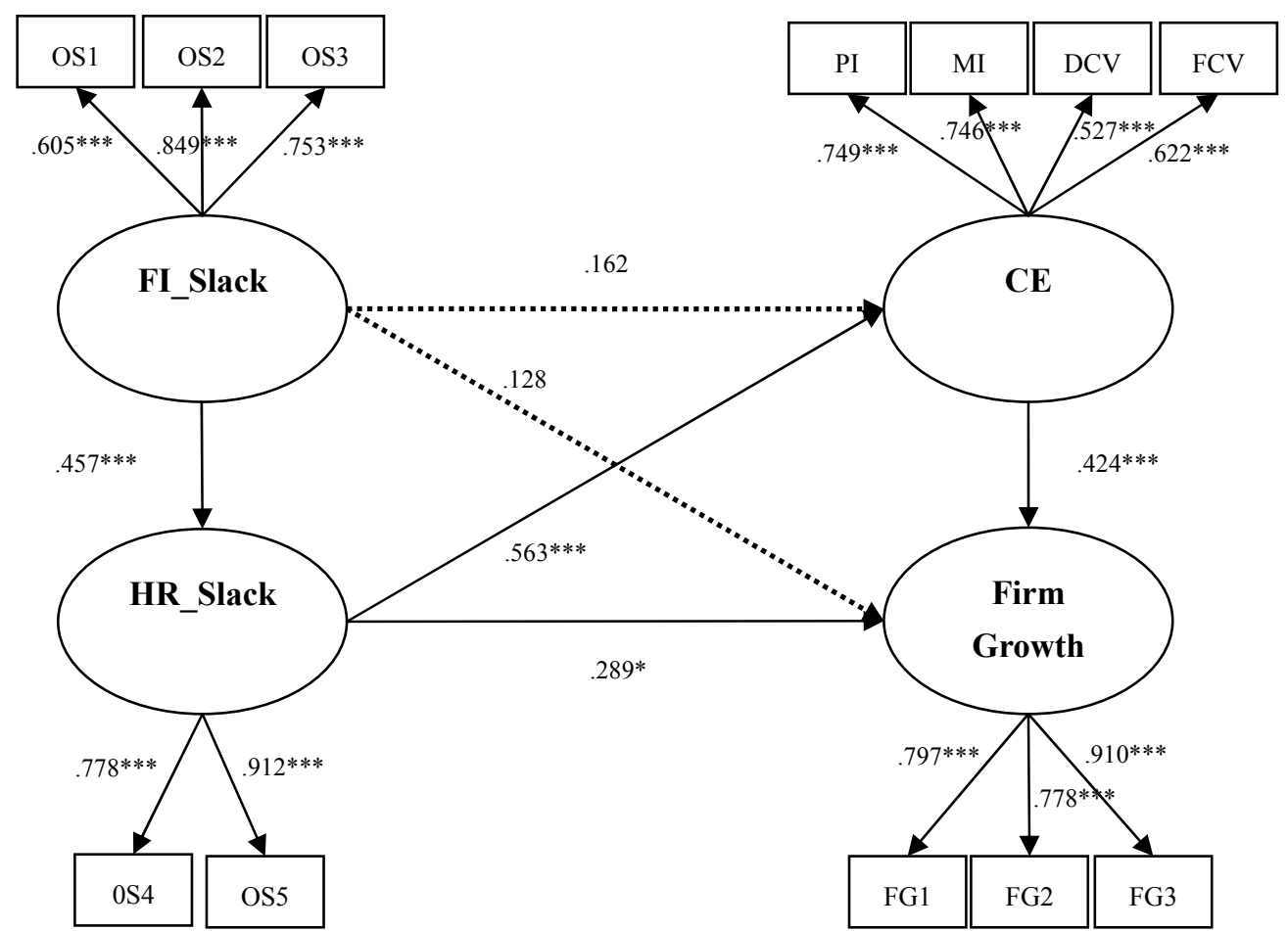

Figure 1. Results of the structural equation modeling

The solid lines represent significant linkages; the dotted lines represent non-significant linkages.

$* \mathrm{p}<0.10 ; * \mathrm{p}<0.05 ; * * \mathrm{p}<0.01$.

\section{Discussion}

\subsection{Organizational Slack Resources and Firm Growth}

Organizational slack resource provides the productive service required by firm growth (Penrose, 1959). While such slack has many positive effects on firm growth (Bourgeois, 1981), not all types of slack resources promote firm growth directly. To clarify the role of slack resource on firm growth, scholars need to go beyond the general definition and look at specific characteristics of different types of resource slack. This study demonstrates that HR slack and financial slack are different in terms of their proactivity. Essentially, with the different levels of proactivity, these two major types of slack resources affect firm growth in different ways. Though financial slack is traditionally considered critically as a prerequisite of firm expansion, our findings indicate that it is unable to directly fuel firm growth due to lower level of proactivity. Our results demonstrate that it is the more proactive HR slack that actually directly mobilizes other sorts of slack resources and utilizes them in spurring firm growth.

\subsection{Slack Resources and Corporate Entrepreneurship}

Organizational slack allows firms to engage in opportunities in their environment at anytime, thereby promoting 
corporate entrepreneurship (Bourgeois, 1981). However, such resource slack may cultivate their complacency behaviors (Jensen \& Meckling, 1976). In this latter case, firms are likely to lack a sense of urgency and are less likely to engage in exploration and actions in response to new opportunities (Simsek, Veiga, \& Lubatkin, 2007). For example, decision makers of firms holding abundant financial slack are more likely to be satisfied with the suboptimal goals. The availability of such resources may actually reduce a firm's initiatives and adaptive behaviors because these resources provide a buffer that isolates the firm from environment turbulences (Simsek et al., 2007). This study demonstrates that resource proactivity is an important dimension of slack resources to analyze the different effect of human resource slack and financial slack in initiating various corporate entrepreneurial activities. The results show that it is the more proactive human resource slack, rather than the financial slack, that allows firms to carry out a variety of entrepreneurial activities.

Corporate entrepreneurship may be interpreted as a dynamic capability that acts as a mechanism for firms to grow. Given the availability of proactive human resource slack, firms are more able to creatively integrate other material resources to instigate a variety of entrepreneurial actions outside their existing boundary and to take advantage of emergent opportunities in their environment. Financial slack itself, on the other hand, may not be able to activate other resources in such manner. Essentially, the successful corporate entrepreneurship is indeed not driven by existing physical or material resources, but instead by professional management and personnel in the organization (Shane \& Venkataraman, 2000). Therefore, firms should create and maintain their professional personnel's entrepreneurial spirit in such a way that they can tap into their entrepreneurial potentials that drive performance and growth.

\section{Conclusion}

Building upon the notion that the slack resources of firms, instead of the total amount of resources, drive firm growth, this study unveils the distinction between human resource slack and financial slack along a crucial dimension of proactivitiy, and highlights the differing effects of human resource and financial slack on firm growth and corporate entrepreneurship.

This paper has provided two theoretical contributions. First, this study lays out a fine-grained view on the relationship between slack resources and firm growth. In the classical work of Penrose (1959), it implies that all sorts of slack resources are directly related to firm growth in that they can provide productive services that fuel firm growth. In this paper, we concentrate on two sorts of slack, human resource slack and financial slack, and posit that they differ along a crucial dimension of 'proactivitiy' which leads to their differing effects on corporate entrepreneurship and firm growth. While human resource slack is directly related to firm growth, financial slack affects firm growth via human resource slack. In doing so, we extend the discussion in the literature on the link between slack resources and firm growth.

Second, this study has demonstrated that the productive services provided by slack resources are translated into firm growth through corporate entrepreneurship, thereby moving beyond the examination of the direct effects of slack resources on firm growth. Indeed, corporate entrepreneurship, as firm-level entrepreneurial efforts, acts as an underlying mechanism through which human resource slack propels firm growth. Particularly, while most of prior research focuses on financial slack, this study demonstrates that human resource slack is instead a driver of corporate entrepreneurship because of its proactivity.

This study has two-fold managerial implications for Chinese firms. First, the result indicates that maintaining slack resources, although with costs, is not without benefits for firm growth. Before 1978, Chinese firms were largely state-owned enterprises operating under the planned economy regime. Because these state-owned enterprises were affiliations of governments, lacking pressure on achieving operational efficiency, they usually kept a high level of redundant resources (Nee, 1992). Since the reform and the implementation of the opening-up policy, the Chinese government has initiated a 'campaign' to reform its state-owned enterprises so that they could cope with increasingly fiercer competitions from nascent privately-owned enterprises and multinational enterprises. In the reform process of Chinese state-owned enterprises, it has long been articulated that firms, in order to improve their efficiencies and competitiveness, have to get rid of any redundant resources. Though meaningful to some extent, such claims may overstate the dark side of slack resources and result in 'putting away the dirty water together with the children'. As this study indicates, financial slack and human resource slack are indeed the sources of productive services that eventually lead to firm growth. In particular, maintaining human resource slack as a strategic resource can spontaneously instigate a variety of corporate entrepreneurial activities and fuel firm growth accordingly. Therefore, it makes sense to reserve valuable human resource slack, particularly in China where sufficiently attracting and retaining high-quality management and technical talents are not easy. 
Second, the results from this study help managers to probe into the types of slack resources in their organization that directly or indirectly drive firm growth. Being a proactive or active resource, human resource slack is directly related to corporate entrepreneurship and subsequent firm growth in that it is able to seek opportunities within the external environment and assemble a variety of resources, thereby exploiting the opportunities for firm growth. In contrast, financial slack, as a passive or inactive resource, is unable to initiate entrepreneurial activities and drive firm growth directly. The realization of their effects on firm growth depends on the existence of proactive human resources, especially human resource slack. Therefore, firms should pay more attention to acquire and maintain the slack of organization talents for use in transforming other physical slack resources and propelling their entrepreneurial activities, thereby increasing their growth potential.

This paper is not without limitations. Although, we have controlled for potential non-observed heterogeneities associated with the level of resource slack, corporate entrepreneurship, and firm growth, the concentrated sample firms in one province in China (e.g., Zhejiang) may bias the results. Future studies should extend this study to some other regions or countries.

\section{Acknowledgements}

This research was supported by the grants from the National Natural Science Foundation of China (Project No. 71202173) and the Zhejiang Provincial Natural Science Foundation of China (Project No. Y7100252 and LY12G02011).

\section{References}

Anderson, J., \& Gerbing, D. (1988). Structural equation modeling in practice: A review and recommended two-step approach. Psychological Bulletin, 103(3), 411-423. http://dx.doi.org/10.1037/0033-2909.103.3.411

Bamford, C. E., Dean, T. J., \& McDougall, P. P. (1997). Initial strategies and new venture growth: An examination of the effectiveness of broad vs. narrow breadth strategies. In P. D. Reynolds, W. D. Bygrave, N. M. Carter, P. Davidsson, W. B. Gartner, C. M. Mason, \& P. P. McDougall (Eds.), Frontiers of Entrepreneurship Research (pp. 375-389). Wellesley, MA: Babson College.

Bourgeois III, L. J. (1981). On the measurement of organizational slack. Academy of Management Review, 6(1), 29-39. http://dx.doi.org/10.5465/AMR.1981.4287985

Brush, T. H., Bromiley, P., \& Hendrickx, M. (2000). The free cash flow hypothesis for sales growth and firm $\begin{array}{llll}\text { performance. } \quad \text { Strategic } & \text { Management }\end{array}$ http://dx.doi.org/10.1002/(SICI)1097-0266(200004)21:4<455::AID-SMJ83>3.0.CO;2-P

Brush, C. G., \& Chaganti, R. (1999). Businesses without glamour? An analysis of resources on performance by size and age in small service and retail firms. Journal of Business Venturing, 14(3), 233-257. http://dx.doi.org/10.1016/S0883-9026(97)00103-1

Chandler, G. N., \& Hanks, S. H. (1994). Market attractiveness, resource-based capabilities, venture strategies, and venture performance. Journal of Business Venturing, 9(4), 331-349. http://dx.doi.org/10.1016/0883-9026(94)90011-6

Cohen, M. D., March, J. G., \& Olsen, J. P. (1972). A garbage can model of organizational choice. Administrative Science Quarterly, 17(1), 1-25. http://dx.doi.org/10.2307/2392088

Cooper, A. C., Gimeno-Gascon, F. J., \& Woo, C. Y. (1994). Initial human and financial capital as predictors of new venture performance. Journal of Business Venturing, 9(5), 371-395. http://dx.doi.org/10.1016/0883-9026(94)90013-2

Covin, J. G., \& Slevin, D. P. (1991). A conceptual model of entrepreneurship as firm behavior. Entrepreneurship Theory and Practice, 16(1), 7-25.

Fornell, C., \& Larcker, D. F. (1981). Evaluating structural equation models with unobservable variables and measurement error. Journal of Marketing Research, 18(1), 39-50. http://dx.doi.org/10.2307/3151312

Greve, H. R. (2003). A behavioral theory of R\&D expenditures and innovations: Evidence from shipbuilding. Academy of Management Journal, 46(6), 685-702. http://dx.doi.org/10.2307/30040661

Jensen, M. C., \& Meckling, W. H. (1976). Theory of the firm: Managerial behavior, agency costs and ownership $\begin{array}{lllll}\text { structure. Journal of } & \text { Financial 305-360. }\end{array}$ http://dx.doi.org/10.1016/0304-405X(76)90026-X

Kraatz, M. S., \& Zajac, E. J. (2001). How organizational resources affect strategic change and performance in 
turbulent environments: Theory and evidence. Organization Science, 12(5), 632-657. http://dx.doi.org/10.1287/orsc.12.5.632.10088

Krishnan, R., Martin, X., \& Noorderhaven, N. G. (2006). When does trust matter to alliance performance? Academy of Management Journal, 49(5), 894-917. http://dx.doi.org/10.5465/AMJ.2006.22798171

Levinthal, D., \& March, J. (1993). The myopia of learning. Strategic Management Journal, 14(S2), 95-112. http://dx.doi.org/10.1002/smj.4250141009

Luo, X., Zhou, L., \& Liu, S. S. (2005). Entrepreneurial firms in the context of China's transition economy: An integrative framework and empirical examination. Journal of Business Research, 58(3), 277-284. http://dx.doi.org/10.1016/S0148-2963(03)00159-0

March, J. G., \& Simon, H. A. (1958). Organizations. New York: Wiley.

Mishina, Y., Pollock, T. G., \& Porac, J. F. (2004). Are more resources always better for growth? Resource stickiness in market and product expansion. Strategic Management Journal, 25(12), 1179-1197. http://dx.doi.org/10.1002/smj.424

Nee, V. (1992). Organizational dynamics of marketing transition: Hybrid firms, property rights, and mixed economy in China. Administrative Science Quarterly, 31(1), 1-27. http://dx.doi.org/10.2307/2393531

Nohria, N., \& Gulati, R. (1996). Is slack good or bad for innovation? Academy of Management Journal, 39(5), 1245-1264. http://dx.doi.org/10.2307/256998

Nunnally, J. C. (1978). Psychometric theory. New York: McGraw-Hill.

Penrose, E. (1959). The theory of the growth of the firm. Oxford: Oxford University Press.

Podsakoff, P. M., MacKenzie, S. B., Lee, J. Y., \& Podsakoff, N. P. (2003). Common method biases in behavioral research: A critical review of the literature and recommended remedies. Journal of Applied Psychology, 88(5), 879-903. http://dx.doi.org/10.1037/0021-9010.88.5.879

Shane, S., \& Venkataraman, S. (2000). The promise of entrepreneurship as a field of research. Academy of Management Review, 25(1), 217-226. http://dx.doi.org/10.5465/AMR.2000.2791611

Sharfman, M. P., Wolf, G., Chase, R. B., \& Tansik, D. A. (1988). Antecedents of organizational slack. Academy of Management Review, 13(4), 601-614. http://dx.doi.org/10.5465/AMR.1988.4307484

Shrader, R. C., \& Simon, M. (1997). Corporate versus independent new ventures: Resource, strategy, and performance differences. Journal of Business Venturing, 12(1), 47-66. http://dx.doi.org/10.1016/S0883-9026(96)00053-5

Simon, H. A. (1957). Administrative behavior. New York: Macmillan.

Simsek, Z., Veiga, J. F., \& Lubatkin, M. H. (2007). The impact of managerial environmental perceptions on corporate entrepreneurship: Towards understanding discretionary slack's pivotal role. Journal of Management Studies, 44(8), 1398-1424. http://dx.doi.org/10.1111/j.1467-6486.2007.00714.x

Spann, M. S., Adams, M., \& Wortman, M. S. (1988). Entrepreneurship: Definitions, dimensions, and dilemmas. Proceedings of the US Association for Small Business and Entrepreneurship, 147-153.

$\mathrm{Su}, \mathrm{Z}$., Xie, E., \& Li, Y. (2009). Organizational slack and firm performance during institutional transitions. Asia Pacific Journal of Management, 26(1), 75-91. http://dx.doi.org/10.1007/s10490-008-9101-8

Tan, J., \& Peng, W. M. (2003). Organizational slack and firm performance during economic transitions: Two studies from an emerging economy. Strategic Management Journal, 24(13), 1249-1264. http://dx.doi.org/10.1002/smj.351

Teece, D. J., Pisano, G., \& Shuen, A. (1997). Dynamic capabilities and strategic management. Strategic Management Journal, 18(7), 509-533. http://dx.doi.org/10.1002/(SICI)1097-0266(199708)18:7<509::AID-SMJ882>3.0.CO;2-Z

Thompson, J. D. (1967). Organizations in action. New York: McGraw-Hill.

Voss, G. B., Sirdeshmukh, D., \& Voss, Z. G. (2008). The effects of slack resources and environmental threat on product exploration and exploitation. Academy of Management Journal, 51(1), 147-164. http://dx.doi.org/10.5465/AMJ.2008.30767373

Yiu, D. W., \& Lau, C. M. (2008). Corporate entrepreneurship as resource capital configuration in emerging market firms. Entrepreneurship Theory and Practice, 32(1), 37-57. 
http://dx.doi.org/10.1111/j.1540-6520.2007.00215.x

Zahra, S. A., \& Covin, J. G. (1995). Contextual influences on the corporate entrepreneurship-performance relationship: A longitudinal analysis. Journal of Business Venturing, 10(1), 43-58. http://dx.doi.org/10.1016/0883-9026(94)00004-E

Zahra, S. A., Sapienza, H. J., \& Davidsson, P. (2006). Entrepreneurship and dynamic capabilities: A review, model and research agenda. Journal of Management Studies, 43(4), 917-955. http://dx.doi.org/10.1111/j.1467-6486.2006.00616.x

\section{Copyrights}

Copyright for this article is retained by the author(s), with first publication rights granted to the journal.

This is an open-access article distributed under the terms and conditions of the Creative Commons Attribution license (http://creativecommons.org/licenses/by/3.0/). 